\title{
The alternative control of powdery mildew complex (Leveillula taurica and Erysiphe sp.) in tomato in the Azapa Valley, Chile
}

\author{
Germán Sepúlveda-Chavera, Ricardo Salvatierra-Martínez, and Rodrigo \\ Andía-Guardia
}

Facultad de Ciencias Agronómicas, Universidad de Tarapacá. Av. General Velázquez 1775, Arica, Chile.

\begin{abstract}
G. Sepúlveda-Chavera, R. Salvatierra-Martínez, and R. Andía-Guardia. 2013. The alternative control of powdery mildew complex (Leveillula taurica and Erysiphe sp.) in tomato in the Azapa Valley, Chile. Cien. Inv. Agr. 40(1):119-130. The powdery mildew complex (Leveillula taurica and Erysiphe sp.) is one of the major factors limiting tomato (Solanum lycopersicum) production in the Azapa Valley, Chile. This problem is especially severe in the case of protected crops because the options for the treatment of these crops with chemical fungicides are limited. This study evaluated the effects of 0.5 and $1.0 \mathrm{~kg} \cdot 100$ $\mathrm{L}^{-1}$ Ospo-V55 ${ }^{\circledR}$ and $10 \%$ raw cow's milk on tomato leaflets infected by powdery mildew complex. Ospo-V55®, with active ingredients consisting of $10 \% \mathrm{p} / \mathrm{p}$ of algae extract (IB-101) and $0.8 \%$ of microorganism concentrate, was evaluated in this study. Ospo-V55® contains flavonoids, alkaloids and phenols, oligo- and polysaccharides, $8.6 \%$ protein, $0.5 \%$ magnesium and trace amounts of riboflavin, niacin and ascorbic acid. Tacora Mas ${ }^{\circledR}$ (a mixture of $25 \%$ tebuconazole and $12.5 \%$ carbendazime) and Acoidal WG (wettable sulfur) were included for comparison with the Ospo-V55® and raw cow's milk treatments. A diagrammatic scale to assess the severity of the disease was validated and used to quantify the damage resulting from tomato powdery mildew and the effects of the treatments. The effect of the treatments on the germination of the conidia of L. taurica and Erysiphe sp. was also studied on water agar. Tacora Mas ${ }^{\circledR}$ provided the best control of powdery mildew in the field, followed by $1.0 \mathrm{~kg} \cdot 100 \mathrm{~L}^{-1}$ Ospo-V55® and Acoidal. However, Ospo-V55® was more effective than Acoidal. All treatments, including raw cow's milk, significantly $(\mathrm{P} \leq 0.05)$ reduced disease severity in the leaf compared with the control. Both surfaces of the leaves were assessed, and better results were obtained on the upper surface. This difference was associated with differences in wetting. Acoidal was the most effective treatment for inhibiting conidia germination, decreasing germination more than $98.2 \%$. This result differed significantly from the value of inhibition produced by Tacora Mas ${ }^{\circledR}$. Ospo-V55 ${ }^{\circledR}$ and raw cow's milk showed significant differences $(\mathrm{P} \leq 0.05)$ in conidial germination compared with the control. Based on these results, we conclude that Ospo-V55 and raw cow's milk can be used in an integrated management program as alternative treatments to control tomato powdery mildew complex.
\end{abstract}

Keywords: Alternative product, conidial germination, Ospo-V55®, powdery mildew, raw cow's milk, severity, tomato, Valle de Azapa.

\section{Introduction}

The tomato (Solanum lycopersicum L.) is the most frequently cultivated vegetable in the world,

Received April 3, 2012. Accepted September 26, 2012. Corresponding author: gsepulve@uta.cl with more than 130 million tons produced per year (FAO, 2008). In Chile, an area of 6,000 ha is used for the cultivation of tomato for fresh consumption. A total of $13 \%$ of the Chilean tomato crop is produced in the Azapa Valley (ODEPA, 2012), where the highest yields of the Chilean 
tomato industry are achieved (ODEPA, 2010). However, diseases are one of the major factors limiting tomato production in Chile (Apablaza, 2000) and worldwide (Agrios, 2005; Nuez, 1995). Among other diseases, powdery mildew has increased in Chile, especially in species of Solanaceae (Moya and Apablaza, 2003). At least in part, this increase is due to the development of new cultivated areas in semi-arid and arid regions of Chile where the lack of crop rotation, intensive soil use and the development of protected tomato crops have increased the prevalence and severity of powdery mildew (Moya and Apablaza, 2003). In the Azapa Valley, tomato powdery mildew is a complex produced by Leveillula taurica (Lev.) Arnaud (Anamorph: Oidiopsis taurica (Lev.) Salmon) and Erysiphe polygoni DC (Anamorph: Oidium balsami Márt), which can occur simultaneously. Their life cycles are closely related to their hosts, and both the sexual and asexual states are produced on living tissues. In a preliminary study, we identified Oidium $s p$. and Oidiopsis taurica affecting tomato and found only L. taurica on S. lycopersicoides in the Azapa Valley (unpublished data).

The powdery mildews can be controlled chemically (Brand et al., 2009; Rongai et al., 2009; Bizi et al., 2008), biologically (hyperparasitism) (Kiss, 2003) or by means of systemic acquired resistance (SAR) (Belanger and Labbe, 2002). However, there is little information about the relative efficiency of these control strategies against the powdery mildew complex of tomato in the Azapa Valley.

Several groups of fungicides, including sulfur and synthetic compounds, have been used to treat powdery mildew (Tsror et al., 2003; IruzunLinhares, 2002, Reuveni et al., 1998). Both sulfur and the synthetic fungicides can be phytotoxic and/or ecotoxic, negatively affecting beneficial organisms (Brand et al., 2009; Coats et al., 2003). Despite the effectiveness of synthetic fungicides and the low cost of sulfur treatments, there is a strong interest in evaluating new methods to control tomato powdery mildew (Brand et al., 2009; Rongai et al., 2009; Bizi et al., 2008; Belanger and Labbe, 2002). Different studies (Belanger and Labbe, 2002; Stadnik and Rivera, 2001 and Bettiol, 1999) have suggested that cow's milk helps to control powdery mildew due to its germicidal effect, induction of SAR and/or tendency to favor the multiplication of antagonists. For instance, Jasper et al. (2009) and Bizi et al. (2008) obtained good results using 10\% cow's milk for the control of E. polygoni and Erysiphe sp., respectively

Visual estimation has been proposed as a method for determining the severity of powdery mildews (Moya et al., 2005). The use of diagrammatic scales is the most common visual method, although it tends to be arbitrary (Tovar-Soto et al., 2002). Alternatively, logarithmic diagrammatic scales, based on the Weber-Fechner Law principle (Horsfall and Barrat, 1945; Nutter Jr. and Schultz, 1995), have been proposed. The logarithmic diagrammatic scales establish classes in a logarithmic system, eliminating the use of arbitrarily designated categories (Tovar-Soto et al., 2002). The objectives of this study were as follows: 1) to evaluate the effectiveness of alternative control methods to manage the powdery mildew complex of tomato and 2) to generate and validate a diagrammatic logarithmic scale for the assessment of the damage caused by powdery mildew in this crop. The species of fungi associated with the powdery mildew complex of tomato in the Azapa Valley of Chile are reported for the first time in this paper.

\section{Materials and methods}

Identification of powdery mildew species present in the Azapa Valley

To identify the causal agent of the powdery mildew complex, tomato leaflets infected with powdery mildew were collected from commercial plantings of tomato (S. lycopersicum) and "tomatillo" $(S$. lycopersicoides) in the Azapa Valley of Chile (18 31'37.4" S and 7009'47.3' W). Conidia 
and micelia of powdery mildew colonies were transferred with the aid of entomological needles to tomato and "tomatillo" plants growing in pots with sterilized substrate (2:2:1, clay loam, fine sand, compost) in the greenhouse. After 10 days, mycelia and conidia of powdery mildew were obtained from leaflets of tomato and tomatillo. Semi-permanent slide preparations of powdery mildew fungi were obtained in lactoglycerol. The length and width of the conidia $(n=100)$ were used to determine the fungal species present. All morphometric measurements were done on the day of collection, and four observations were performed using $40 \mathrm{x}$ magnification with an optical microscope (310 Motic BA, USA).

\section{Fungicides}

The following formulated products were used at the rate specified on the product label: 1) Tacora Mas ${ }^{\circledR}$ (ANASAC, RM, Chile) (25\% tebuconazole plus $12.5 \%$ carbendazime, w/v); 2) Ospo-V55® (Agrotecnología-México, Chile), a biological fungicide with active ingredients consisting of $10 \% \mathrm{p} / \mathrm{p}$ of algae extract (IB-101) and $0.8 \%$ of microorganism concentrate, containing flavonoids, alkaloids and phenols, oligo- and polysaccharides, $8.6 \%$ protein, $0.5 \%$ magnesium and trace amounts of riboflavin, niacin and ascorbic acid; 3) raw cow's milk; and 4) wettable sulfur (Acoidal WG®, BASF, Chile).

\section{Field trials}

Field trials were conducted in a commercial crop of tomato cv. Hybrid Naomi ${ }^{\circledR}$ (Bioamérica, Chile), with 17,000 plants per ha arranged in rows at a spacing of $1.5 \times 0.4 \mathrm{~m}$ in the Azapa Valley in northern Chile (18 $31^{\circ} 37.4^{\prime} S^{\prime}$ ' and $70^{\circ} 09^{\prime} 47.3^{\prime \prime}$ $\mathrm{W})$. These tomato crops were managed according to the traditional standards established in the local production system and included all cultural practices without applications of fungicides. The following six treatments were used, including a water control: $\mathrm{T}_{0}=$ control (water); $\mathrm{T}_{1}=4 \mathrm{~kg} \cdot \mathrm{ha}^{-1}$ Ospo-V55 ${ }^{2} ; \mathrm{T}_{2}=8 \mathrm{~kg} \cdot \mathrm{ha}^{-1}$ Ospo-V55 $\AA ; \mathrm{T}_{3}=3.2$ $\mathrm{kg} \cdot \mathrm{ha}^{-1}$ Acoidal WG (sulfur); $\mathrm{T}_{4}=800 \mathrm{~mL} \cdot \mathrm{ha}^{-1}$ Tacora Mas ${ }^{\circledR}$ (tebuconazole + carbendazime); $\mathrm{T}_{5}=80 \mathrm{~L} \cdot \mathrm{ha}^{-1}$ raw cow's milk. These treatments were applied twice on June 1 and June 8, 2006, covering the upper and lower sides of the leaves. The plants were in the third floral bunch stage of development. The treatments were applied with a SOLO 475® sprayer, using 0.9 L per experimental unit of 20 plants, equivalent to $800 \mathrm{~L} \cdot \mathrm{ha}^{-1}$.

The leaflets above the third floral bunch were assessed every 7 days from the beginning of the experiment on June 1 to June 22, 21 days after application (DAA).

\section{Modification of the diagrammatic assessment scale}

Twenty isolated leaflets showing different severity levels of powdery mildew were scanned by superimposing the leaflets on graph paper and obtaining a digitized image with an HP Scanner (Hewlett Packard Scanjet 8300 Series, USA). This method was used to estimate the total area of the leaflet and the area occupied by each powdery mildew colony. The lower and upper limits of the scale correspond to the minimum and maximum amounts of powdery mildew observed in the field. Subsequently, the diagrammatic scale developed by Martins et al. (2004) for the quantification of foliar damage to end the cycle of soybean (Glycine max), based on Weber-Fechner's law (Horsfall and Barrat, 1945; Nutter Jr. and Schultz, 1995), was used as a reference based on the same mathematical projection made by these authors.

Validation of the diagrammatic assessment scale

Samples of 20 leaflets were evaluated by a panel formed by ten untrained raters based on 100 observations. The estimated severity values 
obtained from each rater were compared with the true (calculated) severity values representing the actual area affected. The correlation between the estimated and true (calculated) severity was determined for each rater with a linear regression analysis. The slope (a) and intercept (b) were obtained from a linear regression of the estimated severity (y) on the true severity (x) for each rater. The accuracy of the visual estimates made by each rater was determined from this regression analysis. The accuracy of each rater was determined by applying a t-test to the regression slope and to the regression intercept. The precision of the estimates was evaluated by calculating the coefficient of determination of the regression $\left(\mathrm{R}^{2}\right)$.

\section{Assessment of the severity of the treatment}

The severity of the powdery mildew in each leaflet was determined using the modified scale described above. The values obtained with the diagrammatic scale for each replication and each treatment were transformed to severity values (the percentage of powdery mildew) with the following expression (Townsend-Heuberger, 1943):

$$
\Sigma(\mathrm{n} \times \mathrm{v}) \times 100 / \mathrm{N} \times \mathrm{V},
$$

where $\mathrm{n}=$ number of sampling units in each category or value on the diagrammatic scale; $v=$ value of each category or value on the diagrammatic scale; $\mathrm{N}=$ total number of sampling units or total leaflets sampled per treatment; $\mathrm{V}=$ maximum value of the category or maximum value of the diagrammatic scale.

\section{Effect of treatments on conidial germination}

To perform this test, sterilized microscope slides were dipped twice in water agar (WA) amended with the same fungicide treatments used in the field experiment and were placed in a Petri dish ( $9 \mathrm{~cm}$ in diameter) containing a wet paper towel.
Conidia from pure colonies of powdery mildew were dusted on the microscope slide and then placed under two different light regimes (total darkness for L. taurica and shadow for Erysiphe sp.) and incubated for $24 \mathrm{~h}$ at $22{ }^{\circ} \mathrm{C}$. Three replicates per treatment were used, and 100 conidia were assessed under $40 \mathrm{x}$ magnification. Conidia were considered germinated if the length of the germ tube was twice the diameter of the conidia.

\section{Statistical analysis}

The relationship between the estimated and calculated severity was determined for each rater with a linear regression, as described above. The significance of the difference between the slope of the regression and a reference value of 1 was evaluated with a Student's t-test. Similarly, the intercept of the regression was tested against a reference value of 0 . The design of the field experiment consisted of completely randomized blocks with six treatments, each with three replicates of ten plants as experimental units. The conidial germination study used a completely randomized design. An analysis of variance was applied to the data, and a Tukey's test was used to evaluate the differences between treatments at $\mathrm{P} \leq 0.05$. Percentage values were transformed prior to analysis. All analyses were performed with StatGraphics Plus 5.1 software (Statpoint Technologies, Inc., Warrenton, Virginia, USA).

\section{Results}

\section{Pathogen identification}

Based on morphological characteristics, the species associated with the powdery mildew complex in tomato in the Azapa Valley were Oidium sp. (Teleomorph: Erysiphe sp.) and Oidiopsis taurica (Teleomorph: L. taurica) (Figure $1 \mathrm{~A}$ and $\mathrm{B}$ ). The sexual stages of these fungi were not observed. 
Modification of the diagrammatic assessment scale

Four theoretical projections of the distribution of the disease for each value of the scale (Figure 1C, Figure 2) were made, generating the following seven reference scores: 0 (affected range 0$) ; 1$ (0.01 to $2.4 \%) ; 2$ (2.4 to $15.2 \%$ ); 3 (15.2 to $25.9 \%) ; 4$ (25.9 to $40.5 \%) ; 5$ (40.5 to $66.6 \%$ ); and 6 (66.6 to $100 \%$ ).

Validation of the diagrammatic assessment scale

The ideal outcome would be that the regression intercept $b=0$ and slope $a=1$ for each rater, indicating that the estimated and calculated severities were equal $(\mathrm{y}=\mathrm{x})$. The coefficient of determination $\left(\mathrm{R}^{2}\right)$ was also obtained for the regressions. Without exception, the t-tests indicated that all calculated a and $b$ values were significantly $(\mathrm{P} \leq 0.05)$ different from 1 and 0 , respectively. For eight raters, the $\mathrm{R}^{2}$ values were between $80 \%$ and $90 \%$; for the two other raters, the $\mathrm{R}^{2}$ values were $75 \%$ and $79 \%$ (Table 1).
Field trials. The validated diagrammatic assessment scale was applied to study the severity of infection and to compare the effects of the treatments on the control of tomato powdery mildew in the field. The effect of the treatments on the severity of tomato powdery mildew was significant for each evaluation date (Table 2). All treatments reduced severity significantly $(\mathrm{P} \leq 0.05)$ relative to the control. In the control treatment, the progress of the disease showed a linear increase at a rate of $3.52 \%$ per day on the lower side of the leaflet and $4.13 \%$ per day on the upper side of the leaflet (Figure 3). For the treatments other than the control, only the data from the lower leaf surface and the data for the cow's milk treatment for the upper surface fit a linear function. However, the treatments applied to the upper side of the leaf yielded the best results (Figure 3, Tables 2, 3). All treatments considerably reduced the rate of disease progression. Tacora Mas ${ }^{\circledR}$ and Ospo $\mathrm{V}-55 \AA\left(1.0 \mathrm{~kg} \cdot 100 \mathrm{~L}^{-1}\right)$ were the most effective treatments, reducing the disease progression rate on the lower leaf surface to $0.38 \%$ and $1.0 \%$ per
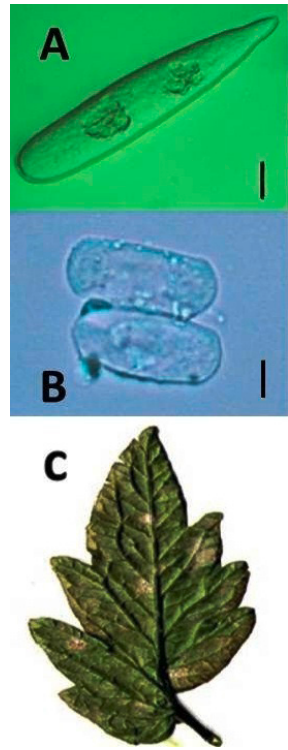

Figure 1. A. Secondary conidium of Odiopsis taurica. B. Conidium of Oidium sp. C. Tomato leaflet with score 2 in the diagrammatic scale used in to evaluation. Bars $=10 \mu \mathrm{m}$.
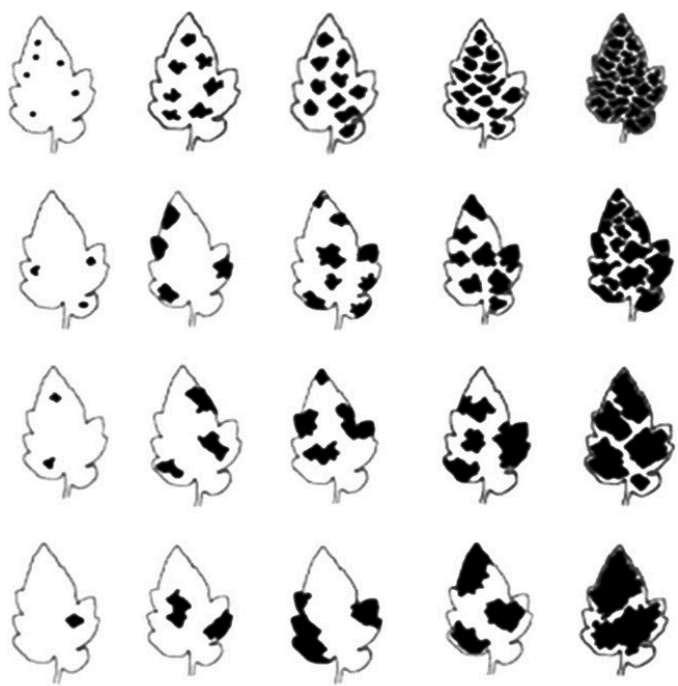

2.4

15.2

25.9

40.5

66.6

Figure 2. Modified diagrammatic scale (developed by the authors) to quantify the severity of powdery mildew in tomato (Solanum esculentum). 
Table 1. Linear regression intercept (b), slope $(a)$ and coefficient of determination $\left(\mathrm{R}^{2}\right)$ for each rater.

\begin{tabular}{lccc}
\hline & \multicolumn{3}{c}{ Coefficients: } \\
\cline { 2 - 4 } Untrained raters & Intercept b & Slope a & Determination $\mathrm{R}^{2}$ \\
\hline 1 & $0.44^{*}$ & $0.90^{*}$ & 0.86 \\
2 & $0.42^{*}$ & $0.87^{*}$ & 0.79 \\
3 & $0.46^{*}$ & $0.84^{*}$ & 0.81 \\
4 & $0.81^{*}$ & $0.78^{*}$ & 0.80 \\
5 & $1.06^{*}$ & $0.74^{*}$ & 0.75 \\
6 & $0.31^{*}$ & $0.88^{*}$ & 0.85 \\
7 & $0.23^{*}$ & $0.93^{*}$ & 0.80 \\
8 & $0.58^{*}$ & $0.87^{*}$ & 0.90 \\
9 & $0.61^{*}$ & $0.81^{*}$ & 0.85 \\
10 & $0.47^{*}$ & $0.87^{*}$ & 0.82 \\
\hline
\end{tabular}

*Situations in which the null hypothesis $(\mathrm{a}=1$ or $\mathrm{b}=0)$ was rejected by the Student $\mathrm{t}$-test $(\mathrm{P} \leq 0.05)$.

Table 2. Regression analysis of severity data calculated with the formula of Townsend and Heub.

\begin{tabular}{llllrr}
\hline & \multicolumn{2}{l}{ Lower surface of the leaves } & & Upper surface of the leaves \\
\cline { 2 - 3 } Treatments & Equation & $\mathrm{R}^{2}$ & & Equation & $\mathrm{R}^{2}$ \\
\hline Control & $\mathrm{y}=3.52 \mathrm{x}+11.68$ & 0.97 & $\mathrm{y}=4.13 \mathrm{x}+4.14$ & 0.99 \\
Ospo-V55 $\left(0.5 \mathrm{~kg} \cdot 100 \mathrm{~L}^{-1}\right)$ & $\mathrm{y}=1.21 \mathrm{x}+11.16$ & 0.94 & $\mathrm{y}=0.02 \mathrm{x}^{3}-0.61 \mathrm{x}^{2}+4.08 \mathrm{x}+6.0$ & 1 \\
Ospo-V55® $\left(1 \mathrm{~kg} \cdot 100 \mathrm{~L}^{-1}\right)$ & $\mathrm{y}=1.06 \mathrm{x}+11.15$ & 0.54 & $\mathrm{y}=0.09 \mathrm{x}^{2}-1.82 \mathrm{x}+12.71$ & 0.99 \\
Tacora Mas ${ }^{\circledR}\left(100 \mathrm{~mL} \cdot 100 \mathrm{~L}^{-1}\right)$ & $\mathrm{y}=0.38 \mathrm{x}+12.38$ & 0.83 & $\mathrm{y}=0.02 \mathrm{x}^{3}-0.61 \mathrm{x}^{2}+4.08 \mathrm{x}+6.0$ & 1 \\
Acoidal $10 \mathrm{~kg} \cdot 100 \mathrm{~L}^{-1}$ & $\mathrm{y}=1.45 \mathrm{x}+8.8$ & 0.75 & $\mathrm{y}=0.02 \mathrm{x}^{3}-0.51 \mathrm{x}^{2}+3.91 \mathrm{x}+4.8$ & 1 \\
Raw cow's milk $10 \%$ & $\mathrm{y}=1.71 \mathrm{x}+9.76$ & 0.95 & $\mathrm{y}=1.32 \mathrm{x}+6.8$ & 0.95 \\
\hline
\end{tabular}
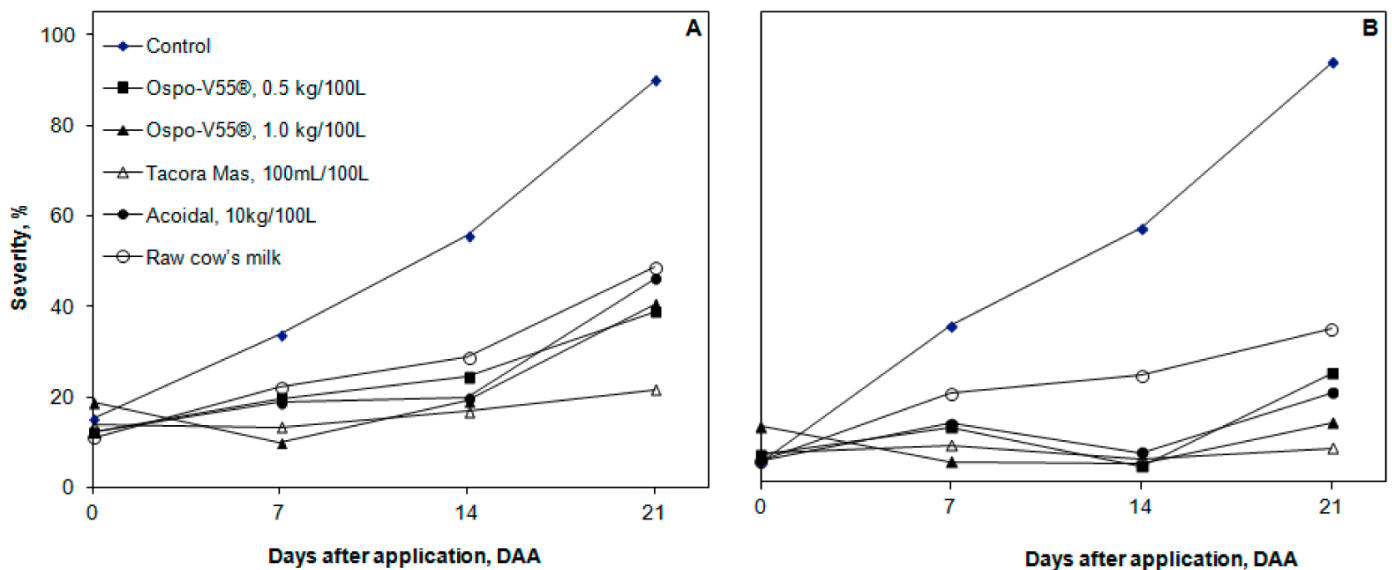

Figure 3. Effect of control treatments on the progress of the severity of tomato powdery mildew in Azapa Valley, Chile. A. Lower leaf surface. B. Upper leaf surface. The powdery mildew severity for each leaflet was determined using the modified scale described in the text. Values obtained with the diagrammatic scale for each replication and for each treatment were transformed to percentage severity values according to Townsend-Heuberger (1943). 
day, respectively (Table 2). At the fourth evaluation (21 DAA) and regardless of the side of the leaflet considered, all treatments reduced the severity of powdery mildew significantly $(\mathrm{P} \leq 0.05)$ relative to the untreated control. However, Tacora Mas ${ }^{\circledR}$ was the most effective treatment, reducing the severity of powdery mildew to $14.6 \%$ (Table $3)$. The application of raw cow's milk resulted in the greatest severity (41.5\%) found for any non-control treatment, but this value was still significantly different $(\mathrm{P} \leq 0.05)$ from that of the untreated controls (Table 3).

Effects on conidial germination. The most effective treatments in inhibiting the germination of conidia of L. taurica and Erysiphe sp. were Acoidal and Tacora Mas ${ }^{\circledR}$. The effects of these treatments differed significantly from those of Ospo-V55 ${ }^{\circledR}$ and raw cow's milk (Table 4). However, all treatments differed significantly $(\mathrm{P} \leq 0.05)$ from

Table 3. Severity of powdery mildew in four evaluations conducted after treatments on the upper and lower leaf surface of tomato cv. Hybrid Naomi ${ }^{\circledR}$.

\begin{tabular}{|c|c|c|c|c|c|c|}
\hline \multirow[b]{2}{*}{ Treatment } & \multirow[b]{2}{*}{ Active ingredient (a.i.) } & \multirow{2}{*}{$\begin{array}{l}\text { Rates }^{1} \\
\times 100 \mathrm{~L}\end{array}$} & \multicolumn{4}{|c|}{ Severity (\%) vs. days after application (DAA) } \\
\hline & & & 0 & 7 & 14 & 21 \\
\hline Water Control & Water & - & $9.85 \mathrm{a}^{2}$ & $34.4 \mathrm{c}$ & $56.15 \mathrm{c}$ & $91.8 \mathrm{c}$ \\
\hline Ospo-V55® & $\begin{array}{l}10 \% \text { algae extract }(\mathrm{IB}-101) \text { and } 0.8 \% \\
\text { microorganism concentrate }\end{array}$ & $0.5 \mathrm{~kg}$ & $9.15 \mathrm{a}$ & $16 \mathrm{ab}$ & $14.05 \mathrm{a}$ & $31.6 \mathrm{ab}$ \\
\hline Ospo-V55® & $\begin{array}{l}10 \% \text { algae extract (IB-101) and } 0.8 \% \\
\text { microorganism concentrate }\end{array}$ & $1.0 \mathrm{~kg}$ & $15.8 \mathrm{~b}$ & $7.35 \mathrm{a}$ & $11.7 \mathrm{a}$ & $27 \mathrm{ab}$ \\
\hline Acoidal WG ${ }^{\circledR}$ & Sulfur & $0.4 \mathrm{~kg}$ & $8.55 \mathrm{a}$ & $15.95 \mathrm{ab}$ & $12.7 \mathrm{a}$ & $33 \mathrm{ab}$ \\
\hline Tacora Mas ${ }^{\circledR}$ & $25 \%$ tebuconazole and $12.5 \%$ carbendazime & $100 \mathrm{~mL}$ & $10.2 \mathrm{ab}$ & $10.1 \mathrm{ab}$ & $10.9 \mathrm{a}$ & $14.6 \mathrm{ab}$ \\
\hline Raw cow's milk & $10 \%$ cow's milk in $90 \%$ water & $10 \mathrm{~kg}$ & $7.9 \mathrm{a}$ & $21 \mathrm{bc}$ & $26.4 \mathrm{~b}$ & $41.5 \mathrm{~b}$ \\
\hline
\end{tabular}

${ }^{1}$ Rates of formulated products.

${ }^{2}$ Mean of three observations. Values followed by the same letter in the same column do not differ significantly (Tukey's test, $\mathrm{P} \leq 0.05$ ). Percent severity values were calculated with the formula of Townsend and Heub.

the untreated controls. The effect of Ospo-V55® $\left(1.0 \mathrm{~g} \cdot 100 \mathrm{~L}^{-1}\right)$ and raw cow's milk did not differ significantly. However, the effects of each of these treatments differed from those of the chemical treatments Tacora Mas ${ }^{\circledR}$ and Acoidal WG. The same treatments were applied to L. taurica (Table 4), and the greatest inhibition of germination was obtained with Acoidal and Tacora Mas ${ }^{\circledR}$, with $14 \%$ and $10.8 \%$ germination, respectively. The least effective treatment was obtained with 0.5 g $100 \mathrm{~L}^{-1}$ Ospo-V55 ${ }^{\circledR}$.

\section{Discussion}

In this study, a diagrammatic scale to evaluate the severity of powdery mildew was proposed based on the logarithmic scale of Martins et al. (2004).
Based on the diagrammatic scale developed in this study, it was demonstrated that Ospo-V55 and raw cow's milk controlled tomato powdery mildew and can serve as alternatives to the use of chemical fungicides in the management of powdery mildew complex (L. taurica and Erysiphe sp.) in tomato. The use of these alternatives would serve to reduce the intensive use of synthetic fungicides.

The validation of the diagrammatic scale with $\mathrm{R}^{2}$ values that exceeded $80 \%$ for most raters suggests that the severity estimates made by the raters were accurate. For this reason, the diagrammatic scale is trustworthy for field use even though the estimates were not $100 \%$ precise (i.e., the slope and intercept of the linear regression used to analyze rater performance were not sufficiently close to 1 and 0 , respectively). This finding does 
Table 4. Effect of control treatments on conidial germination of Oidium sp. and Oidipsis taurica after 24 h of incubation at $22^{\circ} \mathrm{C}$.

\begin{tabular}{|c|c|c|c|c|}
\hline \multirow[b]{2}{*}{ Treatments } & \multirow[b]{2}{*}{ Active ingredient (a.i.) } & \multirow{2}{*}{$\begin{array}{l}\text { Rates }^{1} \\
\times 100 \mathrm{~mL}^{-1}\end{array}$} & \multicolumn{2}{|c|}{ Conidial germination, $\%$} \\
\hline & & & Oidium sp. & O. taurica \\
\hline Control & Water & - & $70 \mathrm{a}^{2}$ & $46.2 \mathrm{a}^{2}$ \\
\hline Ospo-V55® & $10 \%$ algae extract (IB-101) and $0.8 \%$ microorganism concentrate & $0.5 \mathrm{~g}$ & $59.6 \mathrm{ab}$ & $40.2 \mathrm{~b}$ \\
\hline Ospo-V55® & $10 \%$ algae extract (IB-101) and $0.8 \%$ microorganism concentrate & $1.0 \mathrm{~g}$ & $51.2 \mathrm{~b}$ & $33.0 \mathrm{bc}$ \\
\hline Acoidal WG® & Sulfur & $0.4 \mathrm{~g}$ & $1.8 \mathrm{~d}$ & $1.4 \mathrm{e}$ \\
\hline Tacora Mas ${ }^{\circledR}$ & $25 \%$ tebuconazole and $12.5 \%$ carbendazime & $100 \mathrm{~mL}$ & $7.2 \mathrm{c}$ & $10.8 \mathrm{~d}$ \\
\hline Raw cow's milk & $10 \%$ cow's milk and $90 \%$ water & $10 \mathrm{~mL}$ & $52.2 \mathrm{~b}$ & $31.8 \mathrm{c}$ \\
\hline \multicolumn{2}{|c|}{ Coefficient of variation } & & 10.21 & 8.58 \\
\hline
\end{tabular}

${ }^{1}$ Rates of formulated product.

${ }^{2}$ Means of three replicates. Values followed by the same letter in the same column do not differ significantly (Tukey's test, $\mathrm{P} \leq 0.05$ ).

not necessarily imply that the scale cannot be validated and utilized in the field. In contrast, it demonstrates a need to establish clear preevaluation training methods that produce trained raters who can successfully obtain values of the slope and intercept close to 1 and 0 , respectively, furnishing more precise evaluations (Nutter et al., 2006; Moya et al., 2005). The greater the value of $\mathrm{R}^{2}$, the more trustworthy is the scale (Nutter et al., 1991). The estimated values indicate that the diagrammatic scale has high reliability and may be used in field conditions even though a trained rater is required to obtain satisfactory precision.

Previously, the use of digital image analysis has been proposed for crop disease evaluation (Moya et al., 2005). However, the criteria used to define the affected areas that should be identified by the software may be a source of error in this case. These authors indicated that the resolution of the images obtained by a scanner may affect the values obtained from the digital pattern. The severity estimates based on computer programs and standardized evaluation schemes are not mutually exclusive because both methods use the best data applicable to the evaluation of the disease.

The effect of the treatments was greater on the upper surface of the leaves than on the lower surface. The reason for this difference may be the differences between the wetting of the upper and lower leaf surfaces that occurred in the study. Differences in leaf wetting also explain the different functions that fit the progress of the disease for the leaf surfaces. A linear fit was obtained for the lower surface, whereas quadratic or cubic functions were obtained for the upper surface (except for the control). The direct wetting of the upper surface resulted in a drastic reduction of disease. No such drastic reduction occurred on the lower surface, where the wetting was less direct or uneven (Table 2).

Regardless of the leaflet surface considered, the results showed that Tacora Mas ${ }^{\circledR}$, a mixture of carbendazime and tebuconazole, yielded the best reduction in the severity of the disease and substantially reduced the rate of powdery mildew development relative to the control. However, the effect of Tacora Mas ${ }^{\circledR}$ was not significantly different from that of Ospo-V55 $®$ in most evaluations, and Ospo-V55® was also more effective than sulfur (Acoidal WG ${ }^{\circledR}$ ) in three of the four evaluations (Figure 3; Table 3).

Ospo-V55® is a biological product formulated from algal and microorganism extracts. This product contains a number of phenolic, flavonoid and alkaloid compounds. These compounds can increase enzymatic activity (peroxidase and polyphenol oxidase), resulting in a positive 
contribution to the reduction of powdery mildew in Zinnia elegans (Abdelnabi Hegazi, 2010) and other plants (Kohl and Fokkema, 1998; Emeran et al., 2006). Previously, it has been suggested that peroxidase may play a role in the defense mechanisms of the host against pathogen invasions in wheat (Caruso et al., 2001). The peroxidases are involved in the production of lignin because they are phenolic heteropolymers that result from the oxidative coupling of three p-hydroxycinamilic (monolignol) alcohols, p-coumaril (1), coniferyl (2) and sinapyl (3), in a reaction mediated by peroxidases (Gómez-Ros et al., 2007). Peroxidases also produce free radicals and hydrogen peroxide, which are toxic to many microorganisms (Peña and Kuc, 1992). Additionally, Tarrad et al. (1993) indicated that an increase in peroxidase activity improves lignification as a response to infection by pathogens, limiting the penetration of fungi. Ospo-V55 ${ }^{\circledR}$ also reduced the germination of powdery mildew conidia; it showed a germination percentage significantly lower than the control $(\mathrm{P} \leq 0.05)$ and similar to that of raw cow's milk (Table 4), although this decrease was much less than that produced by Tacora Mas ${ }^{\circledR}$ and Acoidal. This reduction may be associated with the effect of one of the alkaloids contained in Ospo-V55 ${ }^{\circledR}$, although additional investigation is necessary to corroborate this.

Raw cow's milk controlled the disease, although it always did so to a lesser degree than the other treatments. Note that spraying with milk produced significant differences from the control, more evident at the last evaluation (two weeks after the last treatment application). In all assessments, the treatments were more effective on the upper leaflets than on the lower leaflets. Cow's milk can be a control alternative for tomato powdery mildew because the severity of powdery mildew in the cow's milk treatment was significantly less than the control $(\mathrm{P} \leq 0.05)$ in all the evaluations (Table 3). The effect of raw cow's milk found in this study agrees with previous findings (Jasper, 2009; Bizi et al., 2008; Bettiol, 1999). Cow's milk stimulates microbiological activity in the phylloplane; moreover, it has a germicidal effect on powdery mildew (Stadnick and Bettiol, 2001). Nevertheless, we did not use coadjuvants or attempt to use higher rates of milk application. These measures have been described as alternatives that can increase the effectiveness of cow's milk (Bizi, 2008; Jasper, 2009).

In this study, sulfur (Acoidal WG ${ }^{\circledR}$ ) was the most effective treatment in reducing the germination of conidia. The reason for this result may be that contact produces fungistatic gases that increases the activity of the agent in closed environments such as a Petri dish. Although Tacora Mas ${ }^{\circledR}$ is composed of two single-action fungicides (tebuconazole and carbendazime), it is still effective against powdery mildew in tomato in the Azapa Valley. However, this product, like sulfur and other chemical fungicides, can be toxic to beneficial organisms. This concern has stimulated the search for new control alternatives (Brand et al., 2009; Coats et al., 2003). Carbendazime is a benzimidazole compound. Resistance to this group of chemicals has been described in powdery mildew fungi and other plant pathogenic fungi (Sedlikovi and Lebeda, 2008; Ma and Michailides, 2005; Elad et al., 1992). Tebuconazole is a triazole compound; resistance to these compounds has been found in Europe, the UK and Australia (Thomas et al., 2011). The reduction of the severity of powdery mildew in tomato by products such as Ospo-V55 ${ }^{\circledR}$ is very possibly a result of SAR induction because the contact and germicidal effects of these products in vitro is minimal. Raw cow's milk reduced the severity of powdery mildew, although it was less effective than Ospo-V55 and chemical fungicides. The effect of raw cow's milk appears to be associated with the induction of defenses and/or the increase of microbiological activity in the phylloplane.

In conclusion, this study demonstrates that Ospo-V55 ${ }^{\circledR}\left(1.0 \mathrm{~kg} \cdot 100 \mathrm{~L}^{-1}\right)$ is an effective alternative for controlling tomato powdery mildew. Nevertheless, additional research is needed to clarify 
its mode of action. Raw cow's milk has a marked effect on tomato powdery mildew. Therefore, it can represent an interesting alternative in cases of low disease pressure.

\section{Acknowledgments}

The authors express their thanks for financial support furnished by projects FIA PYT 20120024 and UTA Mayor 9742-12.

\section{Resumen}

G. Sepúlveda-Chavera, R. Salvatierra-Martínez y R. Andía-Guardia. 2013. Control alternativo del complejo cenicilla (Leveillula taurica and Erysiphe sp.) en tomate en el valle de Azapa, Chile. Cien. Inv. Agr. 40(1):119-130. El complejo cenicilla (Leveillula taurica y Erysiphe sp.) es una de las principales limitaciones en la producción de tomate (Solanum lycopersicum) en el Valle de Azapa, Chile, especialmente en cultivos protegidos donde las opciones de fungicidas químicos se reducen. En este estudio se evaluó el efecto de 0,5 y $1,0 \mathrm{~kg} \cdot 100 \mathrm{~L}^{-1}$ OSPO-V55 ${ }^{\circledR}$ y de la leche de vaca al $10 \%$. OSPO-V55 ${ }^{\circledR} ; 10$ y $0,8 \% \mathrm{p} / \mathrm{p}$ de extracto algas marinas (IB - 101) y concentrado de microorganismos respectivamente, que contiene flavonoides y Alcaloides, fenoles, oligo y polisacáridos, 8,6\% proteínas, 0,5\% de magnesio y cantidades traza de riboflavina, niacina y ácido ascórbico. Para la comparación se incluyeron Tacora Mas ${ }^{\circledR}$, una mezcla de $25 \%$ tebuconazol y el $12,5 \%$ carbendazim, y Acoidal WG, azufre humectable. Fue validada una escala diagramática para evaluar severidad de cenicilla en tomate y esta se utilizó para cuantificar el daño y el efecto de los tratamientos. También se evaluó el efecto de los tratamientos sobre la germinación conidial de L. taurica y Erysiphe sp. Tacora Mas ${ }^{\circledR}$ proporciona el mejor control del cenicilla en campo, seguido OSPO-V55 ${ }^{\circledR} 1,0 \mathrm{~kg} \cdot 100 \mathrm{~L}^{-1}$ y Acoidal. Sin embargo, OSPO-V55 ${ }^{\circledR}$ fue más eficaz que Acoidal $\mathrm{WG} \circledast$. Todos los tratamientos incluyendo la leche de vaca cruda redujeron significativamente $(\mathrm{P} \leq 0,05)$ la severidad de la enfermedad en la hoja en comparación con el control. Ambas superficies de las hojas fueron evaluadas, pero los mejores resultados se obtuvieron en la superficie abaxial, lo que se asoció con diferencias en mojamiento. Acoidal fue el tratamiento más eficaz para inhibir la germinación conidial, sobre un $98,2 \%$, significativamente diferente de Tacora Mas ${ }^{\circledR}$ y a los tratamientos alternativos. OSPO-V55 ${ }^{\circledR}$ y la leche cruda de vaca mostraron diferencias significativas $(\mathrm{P} \leq 0,05)$ en la germinación conidial en comparación con el control. Basándose en estos resultados se concluye que OSPO-V55 y la leche cruda de vaca puede ser un tratamiento alternativo, dentro de un manejo integrado pera el control del complejo cenicilla en tomate.

Palabras clave: Control, germinación conidial, leche de vaca, severidad, Valle de Azapa.

\section{References}

Abdelnabi Hegazi, M., and G. Abdelwanes El-Kot. 2010. Biological control of powdery mildew on zinnia (Zinnia elegans L) using some biocontrol agents and plant extracts. Jour. Agr. Science 2:221-230.
Amano, K. 1986. Host range and geographic distribution of the powdery mildew fungi. Japan Scientific Societies Press, Tokyo, Japan. 741 pp. Apablaza, H. 2000. Patología de cultivos epidemiología y control holístico. Ediciones Universidad Católica de Chile. Santiago, Chile. 347 pp. 
Belanger, R.R., and C. Labbe. 2002. Control of powdery mildews without chemicals: Prophylactic and biological alternatives for horticultural crops: Pages 256-267 In: R.R., Belanger, W.R. Bushnell, A.J. Dik, and T. L. W. Carver (eds.). The powdery mildews, a comprehensive treatise. APS Press. St. Paul (MN, USAA). 292 pp.

Bettiol, W. 1999. Effectiveness of cow's milk against zucchini squash powdery mildew (Sphaerotheca fuliginea) in greenhouse conditions. Crop Protection 18:489-492.

Bizi, R.M.,Jr., A. Grigoletti, C.G. Auer, and L.L. MayDe Mio. 2008. Alternative products to control powdery mildew on eucalyptus seedlings. Summa Phytopathol. 34:44-148.

Brand, M., Y. Messica, Y. Elad, R.D. David, and A. Sztejnberg. 2009. Spray treatments combined with climate modification for the management of Leveillula taurica in sweet pepper. Eur. J. Plant Pathol. 124:309-329.

Bock, C.H., G.H. Poole, P.E. Parker, and T.R. Gottwald. 2010. Plant disease severity estimated visually, by digital photography and image analysis, and by hyperspectral imaging. Critical Reviews in Plant Sciences 29:59-107.

Caruso, C., G. Chilosi, L. Leonard, L. Bertin., P. Magro., V. Buonocore, and C. Caporal. 2001. A basic peroxidase from wheat kernel with antifungal activity. Phytochemistry 58:743-750.

Elad, Y., H. Yunisand, and T. Katan. 1992. Multiple fungicide resistance to benzimidazoles, dicarboximides and diethofencarb in field isolates of Botrytis cinerea in Israel. Plant Path. 41:41-46.

Emeran, A., E. Belal, and H. El-Zahaby. 2006. Biological control of faba bean chocolate spot disease caused by Botrytis fabae. J. Agric. Res. Tanta Univ. 32:243-258.

FAO, 2008. Estadísticas FAOSTAT - Producción agrícola. Available online at: http://faostat.fao. org/site/339/default.aspx (Website accessed: May 31, 2011)

Gomes, A.M., S.J. Michereff, and R.L.R. Mariano. 2004. Elaboração e validação de escala diagramatica para cercosporiose da alface. Summa Phytopath. 30:39-43.
Gómez-Ros, L.V., J.M. Espiñeira, M.J. Pomar, L. Núñez-Flores, and B.A. Ros. 2007. $p-$ Hydroxycinnamyl aldehydes in lignifying plant cell walls. Arkivoc 7:167-171.

Hecht, S. 1924. The visual discrimination of intensity and the Weber-Fachner Law. Jour. General. Physiol. 7:235-267.

Horsfall, J.C., and Barrat, R.W. 1945. An improved grading system for measuring plant diseases. Phytopathology 35:665.

Iruzun-Linhares, A. 2002. Metodología y evaluación de resistencia de Sphaerotheca fuliginea a fungicidas en cucurbitáceas. Universidad Estatal Paulista Julio de Mesquita Filho, Facultad de Ciencias Agronómicas. São Paulo, Brasil. p. 12-13.

Jasper, M., M. Dalla Pria, and A.A. Silva. 2009. Uso do leite de vaca in natura no controle de oídio na cultura da gérbera. Summa Phytopathologica 35:322-324

Kiss, L. 2003. A review of fungal antagonist of powdery mildews their potential as biocontrol agents. Pest Management Science 59:475-483.

Kohl, I., and N.J. Fokkema. 1998. Strategies of biological control of necrotrophic fungal foliar pathogens. Pages 49-88. In: G. Boland, and L.D. Kuykendall (eds.). Plant-Microbe interactions and biological control. Marcel Dekker, Inc., New York.

Ma, Z., and T.J. Michailides. 2005. Advances in understanding molecular mechanisms of fungicide resistance and molecular detection of resistant genotypes in phytopathogenic fungi. Crop Protection 24:853-863.

Martins, M.C., R.A. Guerzoni, G.M. Camara, P. Mattiazzi, S.A. Lourenco, and L. Amorim. 2004. Escala diagramática para aquantificação do complexo de doenças foliares de final de ciclo em soja. Fitopatologia Brasileira 29:179-184.

Moya, E., and G. Apablaza. 2003. El oídio, una amenaza creciente en la producción de pimiento en la zona central. Revista Agronomía y Forestal UC 12:18-21.

Moya, E., A. Barrales, and G. Apablaza. 2005. Assessment of the disease severity of squash powdery mildew through visual analysis, digital image analysis and validation of these methodologies. Crop Protection 24:785-789. 
Nuez, F. 1995. El Cultivo del Tomate. Mundo Prensa. Madrid, España. 793 pp.

Nutter, Jr. F.W., P.S. Teng, and R.M. Shokes. 1991. Disease assessment terms and concepts. Plant Disease 75:1187-1188.

Nutter, Jr. F.W., and P.D. Esker. 2001. Disease assessment keys. Pages: 323-326. In: O.C. Maloy, and T.D. Murray (eds.). Encyclopedia of Plant Pathology. John Wiley and Sons, Inc., NY, USA.

Nutter, Jr. F.W., P.D. Esker, and R.A. Coelho Netto. 2006. Disease assessment concepts in plant pathology. Euro. J. Plant Path.115:95-103.

ODEPA. 2010. Situación del tomate para consumo fresco. Publicación de la Oficina de Estudios y Políticas Agrarias (ODEPA), Ministerio de Agricultura. Gobierno de Chile. Santiago, Chile. ODEPA, 2012. Situación del tomate para consumo fresco. Publicación de la Oficina de Estudios y Políticas Agrarias (ODEPA), Ministerio de Agricultura. Gobierno de Chile. Santiago, Chile.

Peña, M., and J.A. Kuc. 1992. Peroxidase-generated hydrogen peroxidase as a source of antifungal activity in vitro and on tobacco leaf disks. Phytopathology 82:696-699.

Reuveni, R., G. Dor, and S. Reuveni. 1998. Local and systemic control of powdery mildew (Liveillula taurica) on pepper of plant by foliar spray of mono-potassium phosphate. Crop Protection 17:703-709.

Rongai, D., C. Cerato, and L. Lazzeri. 2009. A nature fungicide for the control of Erysiphe betae and Erysiphe cichoracearum. Eur. J. Plant. Pathol. 124:613-619.
Sedlikovi, B., and A. Lebeda. 2008. Fungicide resistance in Czech populations of cucurbit powdery mildews. Phytoparasitica 36:272-289.

Stadnik, M.J. and W. Bettiol. 2001. Pulverização com leite estimula a microflora do filoplano e reduz a severidade do oídio em pepino. Summa Phytopath. 27:109.

Stadnik, M., and M. Rivera. 2001. Oidios. Embrapa Meio Ambiente. Jaguariúna, São Paulo, Brazil. 484 pp.

Tarrad, A. M., Y.Y. El-Hyatemy, and S.A. Omar. 1993. Wyerone derivatives and activities of peroxidase and polyphenoloxidase in faba bean leaves as induced by chocolate spot disease. Plant. Sci. 89:161-165.

Townsend, G.R., and J.W. Heuberger. 1943. Methods for estimating losses caused by diseases in fungicide experiments. Plant Disease Rep. 27:340-343.

Tovar-Soto, A., M.M. Hernández, J. Cristóbal Alejo, R. Romero Hijo, and G. Mora Aguilera. 2002. Escala logarítmica diagramática de severidad de la mancha negra (Colletotrichum gleosporoides) en chirimollo (Annona cherimola). Rev. Mex. de Fitopatología 20:103-109.

Thomas, G., K. Jayasena, C. Beard, and B. Paynter. 2011. Management of barley powdery mildew in the face of fungicide resistance. Farm note 466. Dep. of Agriculture and Food. Gov. of Western Australia. 4 pp.

Tsror, L., S. Lebiush-Mordechai, and N. Shapira. 2003. Control of powdery mildew on organic pepper. IOBC/WPRS Bulletin 26:121-124. 